\title{
Fully integrating upper-secondary vocational and academic courses: A flexible new way?
}

\author{
Cain Polidano $*^{\mathrm{a}}$ and Domenico Tabasso ${ }^{\mathrm{b}}$
}

\begin{abstract}
The tracking of students in upper-secondary school is often criticised for narrowing the postsecondary pathways of student in the vocational education and training (VET) track, which can stigmatise VET. To tackle this problem, countries have introduced courses that integrate aspects of VET and academic study, which provide the dual purpose of preparing students for work and vocational study and providing university pathways for more academic students in the VET track. In this study we assess the latter purpose by examining the outcomes of university aspirants who take these courses in their final year of school. Using rich survey and administrative data from Australia and propensity score matching we find that these courses are associated with lower academic performance and a lower chance of attaining a university offer. Decomposition results show that poor performance in integrated courses is the main driver, which points to potential tension between the two purposes.
\end{abstract}

JEL Codes: I20, I23, J24.

Keywords: Propensity score matching, university access, vocational education and training.

*Corresponding author. Tel: +61 38344 2102; E-mail address: cainp@unimelb.edu.au.

${ }^{a}$ Melbourne Institute of Applied Economic and Social Research, University of Melbourne; Australian Research Council Centre of Excellence for Children and Families over the Life Course.

${ }^{\mathrm{b}}$ Geneva School of Economics and Management, University of Geneva; NCCR Lives, and IZA (Bonn).

Acknowledgements: Funding and support for this project was provided by the Australian Government Department of Industry through the National VET Research program managed by the National Centre for Vocational Education Research. The authors would like to thank staff from the Victorian Department of Education and Training (VDET); the Victorian Curriculum and Assessment Authority (VCAA) and the Victorian Tertiary Admission Centre (VTAC) for making the data available for this project and for providing very helpful feedback on an earlier draft of this paper. The views and opinions expressed in this document are those of the authors and do not necessarily reflect the views of the Australian Government, State and Territory governments, VDET, VCAA, VTAC, or NCVER. The authors thank Rong Zhang for helping to prepare the data for an earlier version of this paper, Juerg Schweri and participants at the SFIVET Congress 2015 and the ISER Multidisciplinary Workshop in Education 2015 for comments and suggestions. 


\section{Introduction}

A challenge for upper-secondary schooling around the world is how to ensure enough flexibility in the curriculum to cater for post-secondary pathways that require different learning approaches and academic abilities. In the main, countries have approached this challenge by providing separate tracks in academic and vocational education and training (VET) study, with participation in one or the other determined either by choice (common in English-speaking countries) and/or by performance in academic tests (German-speaking countries and Southern Europe). A criticism of tracking is that the curriculums of the two tracks are often incompatible, so that VET courses can potentially limit access to university for students who are on the margin between the two tracks (Eichhorst, et al. 2015). ${ }^{1}$ In countries where there is strong emphasis on university study, the result is that uppersecondary VET courses are stigmatised as being a 'second-choice option' (OECD 2000; Kogan 2008).

There are two main ways in which countries have attempted to deal with the stigmatisation of VET courses in upper-secondary education. The first is to establish technical colleges that provide vocationally oriented university-level qualifications (ISCED 5A and above) for students in the upper-secondary VET track. This model is found in countries such as Ireland, Switzerland and Finland. The other main model, which is consistent with OECD (2014) recommendations, is to provide university pathways for students from the upper-secondary VET track. To this end, an approach favoured by English-speaking countries including United States, England and Australia has been to introduce integrated VET courses to the uppersecondary curriculum. ${ }^{2}$ These courses combine aspects of academic courses, such as theory and mathematical principles, with task-focussed, work-centred aspects of VET in areas such as information technology, business, engineering and the arts. ${ }^{3}$

In principle, integrated VET courses are appealing for students on the margin between tracks because they allow them to explore vocational pathways and develop relevant employment

\footnotetext{
${ }^{1}$ While it is true that there are pathways between upper-secondary VET and university study, including in countries where there is streaming on academic ability, in practise the divergent level of skills and competences required means that it is not common (Woessmann 2008).

${ }^{2}$ Integrated courses are also part of apprenticeship schemes in Switzerland and Austria that help with articulation between VET and university study (Fazekas and Field, S. 2013; Kuczera and Field, 2013).

${ }^{3}$ In the United States, Career Academies offer integrated courses that are relevant to local skill needs on a small scale within select high schools. Importantly, career academy courses meet entrance requirements for four-year colleges and universities. In England, BTEC (Business and Technology Education Council) level 3 VET courses and above have A-level equivalent status, which means performance counts towards university entry. In Australia, some states offer integrated VET courses in select fields. Performance in these courses count towards both a national VET qualification and university entry.
} 
skills without harming their academic achievement and their chances of attaining university entry. However, in practice, it is unclear whether taking these courses, instead of a conventional academic course, leaves academic achievement and the chances of university entry unharmed for aspiring students. First, these courses are designed to meet dual and possibly conflicting objectives: to open-up pathways to university in the VET track and prepare students for work and further vocational study, which may compromise outcomes. For example, more academic students may not be well suited to the 'hands-on' learning approach of VET, which is often claimed to better suit less academic students (Smith 2002). Second, because integrated VET classes contain more low-ability students who enrol for purely for employment reasons, the academic performance of university aspiring students may be negatively affected (Ding and Lehrer 2007). Third, there may be negative spill-over effects on their performance in other academic courses because of incompatibility, in scheduling and content, with integrated VET courses. On the other hand, spill-over effects may be positive if integrated VET courses motivate greater performance in academic courses by providing the 'real-world' context in which theory can be applied (Kolb 1984).

In this paper, we provide evidence of whether integrated VET courses are meeting their primary objective of opening-up opportunities for upper-secondary VET students to enter university. More specifically, we estimate the impacts of taking an integrated VET course on final year academic achievement and receipt of a university offer among students who apply for university entry in the Australian state of Victoria. While there may be other objectives from integrated VET, such as improvements in university performance and labour market outcomes, these are not examined here. ${ }^{4}$ There are two main benefits from examining education outcomes in Victoria. First, Victorian integrated courses attract students from across the academic spectrum, mainly because performance counts towards both university entry and a national VET qualification for employment in semi-skilled entry-level jobs. Thus, if there are difficulties accommodating the dual employment and academic objectives of integrated VET courses, we should observe them in this context. Second, we are able to exploit rich population administrative and survey data that help us deal with self-selection (for example, past performance in national standardised tests and school-level factors) and provide us with accurate measures of academic performance and the receipt of a university offer. Estimation is conducted using propensity score matching, which allows us to control for

\footnotetext{
${ }^{4}$ Currently, long-term outcomes from integrated VET courses in Australia are not present in available data collections.
} 
differences in the observable characteristics and the academic ability of university applicants who did or did not take integrated VET courses.

This paper makes two important contributions to the existing literature. First, we provide evidence on the effects of integrating vocational courses into an academic upper-secondary school curriculum. Previous studies have focussed on estimating the impacts on school retention and labour market outcomes from taking purely vocational upper-secondary VET courses that are designed for meeting the needs of less academic students who are preparing for work or further vocational study (Kang and Bishop 1989; Bishop and Mane 2004 and Meer 2007; Polidano and Tabasso 2014). Our results provide the first evidence of the effectiveness of integrated VET courses in accommodating the needs of more academicoriented students. Such evidence is important in helping policy makers and schools assess the effectiveness of integrated VET courses in providing multiple post-school pathways and improving the status of upper-secondary VET.

Our second contribution is the development of an approach to decompose any estimated effects into direct and indirect effects. A direct effect is the score in an integrated VET course relative to the score if an academic course was chosen instead, while an indirect effect is the spill-over effect on achievement in academic courses if an integrated VET course is taken. This decomposition approach sheds light on the mechanisms through which effects are transmitted, and depending on the direction of indirect effects, signals whether integrated VET and academic courses are complements or substitutes in academic achievement. Evidence to date shows that in the eyes of employers, VET and academic courses are complements (Kang and Bishop 1989; Bishop and Mane 2004).

We find that among students who apply for university entry prior to sitting final exams, taking an integrated VET course is associated with 5 percent lower academic achievement in the final year of school. Associated with the lower achievement is an estimated 8 percentage point lower chance of receiving a university offer. Using our decomposition approach, we find that around $70 \%$ of the gap in academic achievement in the final year of school is related to a direct effect, or relatively weak performance in integrated VET. We find that in the main, students on the margin of attaining entry to university (second top quartile in national numeracy and literacy tests) attain higher scores in academic subjects than in integrated VET courses. These findings call into question the effectiveness of integrated VET courses in meeting their dual objectives. 
In the following sections we describe the Australian education system (section 2), provide an overview of the data (section 3) and econometric method (section 4), discuss the results (section 5) and present conclusions and implications (section 6).

\section{Integrated VET courses and upper-secondary education in Australia}

Upper-secondary education in Australia, like in many other English-speaking countries, is untracked and geared towards preparation for university, the main form of post-secondary education. Around $50 \%$ of young Australians are expected to attain a university level qualification over their lifetime, compared to 39\% across the OECD (OECD 2013). The high rate of university participation is due in part to the long-established and universally available deferred loans scheme and government subsidies of university qualifications. For those who do not go onto university study, post-secondary VET study is a popular option.

There are limited places available at Australian universities and access is rationed at the university course level, mainly based on university entry scores (see section 3.1) that measure academic performance in the last year of secondary school (Year 12). ${ }^{5}$ Typically, more desirable university courses, such as medicine and law, and more desirable universities, set higher minimum entry scores for admission. University applications are centrally administered. To apply, students are required to list their preferred courses in order of priority from 1 (most preferred) to 12.

In the Australian upper-secondary curriculum, there are two types of VET courses traditional VET courses, which lead to a national VET qualification, and integrated VET courses, which count towards both a national VET qualification and university entry. Integrated VET courses were introduced into the upper-secondary curriculum in the late 1990s in varying degrees across states with the aim of broadening the appeal of VET to more academic students to address the stigmatisation of traditional upper-secondary VET courses. ${ }^{6}$ In this paper, we focus on examining the outcomes from taking integrated courses in the state of Victoria, where these courses were first introduced. In 2011, the year of enrolments examined in this study, there were 27 VET courses available to students in Year 12 in Victoria, 17 of which were integrated VET courses.

\footnotetext{
${ }^{5}$ In 2013 the Australian Government introduced an entitlement to a publicly-funded place in university for all Australian students, but access remained subject to capacity constraints. This tended to increase the proportion of students enrolled in university and reduced the minimum academic requirement for entry. This reform does not affect the cohort examined in this paper.

${ }_{6}$ As outlined in the policy document New framework for vocational education in schools (Ministerial Council on Employment Education and Training and Youth Affairs (MCEETYA) 1999).
} 


\section{Data}

A feature of our analysis is the use of rich population unit-record data of Victorian Year 12 completers in 2011 from all school sectors (government, Catholic and independent private). The data comprise information from three linked administrative datasets on schools, student academic performance and university applications; providing information on key variables including school characteristics, past performance in national standardised test scores (NAPLAN), university entry scores; and university applications prior to completing the final year of school. These datasets were linked using a de-identified student number common to each of the datasets, which ensured that the datasets could be linked with close to $100 \%$ accuracy. We also link-in at the individual level self-reported information on whether or not a university offer was received. This information comes from the On-track survey, a survey of 34,000 graduates conducted around 6 months after graduation. ${ }^{7}$

Overall, we observe 48,408 Year 12 school completers in Victoria in 2011, of which 3,628 (or 7.4\%) took at least one integrated VET course and 44,780 did not (Table 1). The most popular integrated VET courses are Interactive Digital Media; Community Recreation and Sport and Outdoor Recreation; Hospitality; Hospitality (kitchen operations); Music; Music Industry; Information Technology and Electrotechnology and Business.

\footnotetext{
7 For more information on On Track, including the survey questionnaires, visit the On Track website: http://www.education.vic.gov.au/about/research/Pages/ontrackdata.aspx.
} 


\begin{tabular}{|c|c|c|c|c|c|}
\hline & $\begin{array}{c}\text { Total } \\
\text { number of } \\
\text { students }\end{array}$ & $\begin{array}{c}\text { Less } \\
\text { number } \\
\text { without a } \\
\text { an entry } \\
\text { score }\end{array}$ & $\begin{array}{c}\text { Less } \\
\text { number } \\
\text { without } \\
\text { Year 9 } \\
\text { NAPLAN }\end{array}$ & $\begin{array}{c}\text { Less } \\
\text { number } \\
\text { who don't } \\
\text { attain a } \\
\text { study score } \\
\text { for } \\
\text { integrated } \\
\text { VET } \\
\end{array}$ & $\begin{array}{c}\text { Less } \\
\text { those who } \\
\text { do not } \\
\text { intend to go } \\
\text { to } \\
\text { university }\end{array}$ \\
\hline \multicolumn{6}{|l|}{ Integrated VET course } \\
\hline Business & 257 & 191 & 165 & 162 & 124 \\
\hline Community recreation & 572 & 469 & 420 & 411 & 267 \\
\hline Community services & 274 & 208 & 180 & 173 & 133 \\
\hline Dance & 90 & 74 & 59 & 57 & 44 \\
\hline Electrotechnology & 96 & 63 & 48 & 45 & 15 \\
\hline Engineering studies & 146 & 113 & 103 & 98 & 50 \\
\hline Equine industry & 49 & 40 & 36 & 32 & 21 \\
\hline Financial services & 8 & 7 & 5 & 5 & 3 \\
\hline Furnishing & 102 & 83 & 75 & 73 & 25 \\
\hline Hospitality & 338 & 253 & 209 & 205 & 130 \\
\hline Hospitality (kitchen operations) & 297 & 228 & 194 & 188 & 106 \\
\hline Information technology & 241 & 186 & 161 & 150 & 112 \\
\hline Interactive digital media & 660 & 526 & 460 & 451 & 324 \\
\hline Laboratory skills & 9 & 8 & 8 & 8 & 8 \\
\hline Music & 128 & 112 & 99 & 96 & 68 \\
\hline $\begin{array}{l}\text { Music industry (technical } \\
\text { production) }\end{array}$ & 253 & 186 & 162 & 162 & 98 \\
\hline Sports and outdoor recreation & 108 & 88 & 77 & 71 & 55 \\
\hline Takes an integrated VET course & 3,628 & 2,835 & 2,461 & 2,387 & 1,583 \\
\hline $\begin{array}{l}\text { Doesn't take an integrated VET } \\
\text { course }\end{array}$ & 44,780 & 36,070 & 30,380 & 29,998 & 25,854 \\
\hline
\end{tabular}

Note: Students with multiple integrated VET course enrolments, students with less than 5 scored courses and students with missing observations for control variables are also omitted.

In defining our sample for analysis, we omit a number of observations. First, we omit those who do not attain a university entry score at the end of Year 12. Students may not attain a university entry score if they do not complete requirements of the course, for example, if they commence Year 12, but dropout before the end of the year. Second, we omit those without a Year 9 NAPLAN score, an important control variable in the matching procedure. Although sitting Year 9 NAPLAN tests is compulsory, students can be exempt from sitting the tests if they have a complex disability, if they are from a non-English speaking background and have arrived in Australia within a year, or if they have written consent from a parent or guardian. ${ }^{8}$ Third, we omit those who attain a university entry score, but do not attain a score for their VET course. Students who take integrated VET courses can opt out of having their

\footnotetext{
${ }^{8}$ Students with a disability or from a non-English speaking background who have arrived in Australian within a year are still encouraged to sit the tests. Extra support is available for members of these groups if they choose to sit the exams.
} 
achievement in the course scored, in which case they do not sit an exam in this course. In these rare cases, a student's university entry score will be made-up from a combination of their typically remaining 4 courses. To ensure that all of our VET group get the same intensity of treatment, we also omit a handful of students who choose more than one integrated VET course. Fourth, because we are interested in estimating the impacts of taking integrated VET courses on university access, we omit those who do not apply for admission to a university course prior to sitting their final exams (before the end of October 2011).

\subsection{Outcomes of interest}

The main outcome of interest is academic achievement in Year 12, measured by a student's university entry score. University entry scores are derived by summing the highest score for English (from English, English as a Second Language or English Literature) with the remaining best three course scores (known as the primary four courses) and adding $10 \%$ of the fifth-best course score. If a sixth course is taken, which is not the norm, an additional $10 \%$ of a sixth course is included as well. Because each course is out of a possible 50, the maximum university study score is 205 (or 210 if students take 6 courses). All students who complete Year 12 receive an entry score regardless of whether or not they apply to university.

Any impact on university entry scores from taking integrated VET courses does not necessarily imply that their chances of receiving a university offer are affected. The receipt of an offer also depends on the minimum entry scores of the courses that the students apply to. In some cases, admission is also based on non-academic criteria, such as socio-economic background and/or performance in an interview.

To estimate impacts on the chances of receiving an offer, we use two measures. First, we impute the receipt of an offer by comparing the minimum entry scores for admission to courses that students apply to with their realised entry scores. We assume that students receive an offer if their university entry score is higher than the lowest necessary score for admission to any of their preferred courses. Similarly, we also impute measures for the receipt of an offer that is in the student's top three most preferred courses and receipt of an offer in the student's top six. Second, we use self-reported receipt of an offer from the On Track survey of 2011 graduates, conducted around six months after school graduation. Receipt of an offer in On Track is identified by whether graduates report ever being enrolled in a university course (regardless of whether they are still studying), whether they received an offer and deferred, or whether they received an offer and declined. The use of self-reported receipt is important 
because it will capture offers that are related to performance in criteria that are unrelated to academic achievement.

\subsection{Descriptive statistics}

In Table 2 we present mean values for each of our outcome measures and for key control variables used in our analysis. Mean values for other controls used in the analysis are provided in Table A1 in the appendix.

Within our sample, students who take integrated VET courses on average attain a university entry score that is 17 points (13\%) lower than those who do not. This raw difference is large, but is likely to be in part explained by self-selection bias - differences in the characteristics of students who do and do not take integrated VET courses. For example, those who take integrated VET courses have lower academic ability, measured by performance in national numeracy and literacy tests. On average, students who take an integrated VET course score 590 and 587 (out of 874) in national numeracy and reading tests respectively, compared to 622 and 613 those who do not take an integrated VET course. The former are also less likely to have a parent with a university (bachelor) degree, are more likely to be male, come from areas where there is slightly higher unemployment and are more likely to attend public schools.

A point of note is that as well as having lower academic ability on average, those who take integrated VET courses also apply for university courses that have less competitive entry requirements, measured by the lower minimum entry scores for admission. For applicants who take an integrated VET course, on average, their most preferred university course requires an entry score in the top 40th percentile for admission, compared to the top 30th percentile for applicants who do not take an integrated VET course (Table 2). Despite applying to courses with lower university entry scores, students who take integrated VET courses appear less likely to receive a university offer, regardless of whether we use the imputed or self-reported measure. For both measures, there is around a 20 percentage point gap in the receipt of an offer.

Although these figures indicate some observed differences in the characteristics of university applicants who do and do not take integrated VET courses, the difference are not so great that they cannot be adjusted for using econometric techniques. 


\begin{tabular}{|c|c|c|c|c|}
\hline & \multicolumn{2}{|c|}{$\begin{array}{l}\text { Applied for university } \\
\text { (sample for analysis) }\end{array}$} & \multicolumn{2}{|c|}{$\begin{array}{l}\text { Did not do not apply for } \\
\text { university (omitted from the } \\
\text { sample) })^{\mathrm{a}}\end{array}$} \\
\hline & $\begin{array}{l}\text { Integrated } \\
\text { VET } \\
\text { students }\end{array}$ & $\begin{array}{l}\text { Other } \\
\text { students }\end{array}$ & $\begin{array}{l}\text { Integrated } \\
\text { VET } \\
\text { students }\end{array}$ & $\begin{array}{l}\text { Other } \\
\text { students }\end{array}$ \\
\hline \multicolumn{5}{|l|}{ Outcome variables } \\
\hline University entry score (out of 205) & 111.32 & 128.59 & 93.15 & 92.00 \\
\hline \multicolumn{5}{|l|}{ Imputed receipt of a university offer } \\
\hline Offered any place (\%) & 55.89 & 75.06 & - & - \\
\hline Offered a top 3 course (\%) & 40.57 & 53.37 & - & - \\
\hline Offered a top 6 course (\%) & 50.99 & 67.93 & - & - \\
\hline Self-reported receipt of a university offer (\%) & 67.65 & 86.39 & - & - \\
\hline \multicolumn{5}{|l|}{ Key student characteristics ${ }^{b}$} \\
\hline Male (\%) & 50.47 & 44.94 & 59.88 & 51.10 \\
\hline Indigenous students (\%) & 0.19 & 0.23 & 0.20 & 0.57 \\
\hline Non-English speaking background (\%) & 27.80 & 30.99 & 22.42 & 20.58 \\
\hline Unemployment rate in SLA (\%) & 5.71 & 5.29 & 5.68 & 5.63 \\
\hline NAPLAN numeracy score in Year 9 (out of 874) & 589.63 & 622.19 & 573.53 & 575.79 \\
\hline NAPLAN reading score in Year 9 (out of 874) & 586.87 & 612.94 & 570.19 & 573.35 \\
\hline $\begin{array}{l}\text { Minimum percentage rank of university entry } \\
\text { score to attain first course preference (out of 100) }\end{array}$ & 60.56 & 69.69 & - & \\
\hline Number of individuals & 1,583 & 25,854 & 992 & 5,080 \\
\hline
\end{tabular}

${ }^{\mathrm{a}}$ This sample includes the same restrictions as the sample for analysis except that these individuals do not apply for university study. ${ }^{\mathbf{b}}$ See Table A1 in the Appendix for mean values of all control variables in our analysis. ${ }^{\mathbf{c}}$ This control is not included as part of the standard analysis because it contains a large number of missing observations. However, it is included as part of the sensitivity analysis in section 5.3.

\section{Estimation strategy}

As discussed above, part of the raw difference in university entry scores and the chances of receiving an offer observed in the raw data (Table 2) is likely to be due to self-selection and not due to the impacts of taking an integrated VET course. In the absence of exogenous variation that could be exploited, for example as part of an instrumental variables (IV) strategy, to attempt to isolate causal effects, we rely on the richness of controls in our data and propensity score matching (PSM). PSM deals with self-selection by constructing a 'like' or 'matched' control group (from students who do not take an integrated VET course) against which outcomes from the treatment group (those who take an integrated VET course) can be compared to isolate the effects of the treatment (taking an integrated VET course). A limitation of PSM is its heavy reliance on rich data to control for differences in all factors that 
affect both selection and outcomes, known as the conditional independence assumption (CIA).

Ideally, to ensure that the CIA holds, we would restrict the matched control group to individuals who took the same courses as those of the treatment group, except for one, the integrated VET course. However, given that students have great flexibility in choosing from around 60 Year 12 courses, such an approach would impose a tight constraint on the matching and any estimates would be arbitrarily based on choosing a specific academic course as an alternative to taking an integrated VET course. We avoid this problem by constructing counterfactual outcomes from the weighted average scores of all academic courses taken by the matched control group, even though the academic courses taken by the two groups may be somewhat different. This is not likely to be a limiting assumption because we find that there are only minor differences in the academic courses chosen between the integrated VET and matched control groups (Table A2 in Appendix A).

In the standard analysis, we apply the Kernel matching approach, which utilises information from a number of matched control group observations rather than just a handful as is the case for Nearest Neighbour. The use of multiple matched control group observations means that in many applications Kernel has the advantage of greater efficiency, but may be more prone to bias (Smith \& Todd 2005). To test for any bias, we also generate results using one-to-one and closest five Nearest Neighbour as part of the sensitivity analysis (section 5.3). ${ }^{9}$

\subsection{Decomposition approach}

A key feature of this paper is the derivation of a decomposition method to explain any gap in university entry scores between those who do and those who do not take integrated VET courses. As described in the text, an individual's university entry score is derived by summing the highest English study score with the remaining best three course scores (known as the primary four) and adding $10 \%$ of the scores of other courses taken (usually only one other): ${ }^{10}$

$$
S_{i}=X_{E_{n g l i s h}}+\sum_{c=1}^{N_{i}} w_{i c} X_{i c}
$$

where,

\footnotetext{
${ }^{9}$ When performing the Kernel matching procedure we employ a conservative bandwidth of 0.02 .

${ }^{10}$ If a sixth course is taken (not the norm), an extra $10 \%$ of that course is added as well, which would mean adding $0.1 x_{i 6}$ to equation (1).
} 
$X_{\text {iEnglish }}=$ highest score in English, English as a second language or English literature for student $i ;^{11}$

$X_{i c}=$ score in course $c$ (other than English) for student $i$;

$w_{i c}=$ weight of score for course $c$ for individual $i$, which is 1 for the best three course scores and 0.1 otherwise;

$N_{i}=$ number of courses taken by student $i$, excluding English (typically 4).

For individual $i$, the effect of taking an integrated VET course on the university entry score is the difference in the university entry score if an integrated VET course is taken $\left(s_{i}\right)$ minus the entry score if an academic course is taken instead $\left(s_{i}^{\prime}\right)$ :

$$
s_{i}-s_{i}^{\prime}=\left[x_{E n g l i s h}+\sum_{k=1}^{N_{i}-1} w_{i k} x_{i k}+w_{i V E T} x_{i V E T}\right]-\left[x_{E n g l i s h}^{\prime}+\sum_{k=1}^{N_{i}-1} w_{i k}^{\prime} x_{i k}^{\prime}+w_{i A} x_{i A}\right]
$$

where,

$w_{i k}, x_{i k}=$ weights and scores for academic course $k$;

$w_{i V E T}, x_{i V E T}=$ weights and scores for an integrated VET course;

$w_{i A} X_{i A}=$ weights and scores for an academic course $A$ that is taken instead of an integrated VET course;

$w_{i k}^{\prime}, X_{i k}^{\prime}=$ weights and scores in the same $k$ academic courses if another academic course $(A)$ is taken instead of an integrated VET course;

$X_{i E n g l i s h}^{\prime}=$ score in the highest English course if an academic course $(A)$ is taken instead of an integrated VET course.

We assume that the effect of taking an integrated VET course (equation (2)) on university entry scores is the sum of two effects - a direct and an indirect effect. For individual $i$, the direct effect $\left(D E_{i}\right)$ is the weighted score from taking an integrated VET course, relative to the weighted score if an academic course was taken instead, all else being equal. The indirect effect $\left(I E_{i}\right)$, or spill-over effect, is the weighted sum of course scores in all academic courses when an integrated VET course is taken relative to when an academic course $(A)$ is taken instead:

\footnotetext{
${ }^{11} 94 \%$ of students in our sample only take one English course.
} 


$$
\begin{gathered}
D E_{i}=\left[w_{i V E T} X_{i V E T}\right]-\left[w_{i A} X_{i A}\right] \\
I E_{i}=\left[X_{E_{n g l i s h}}+\sum_{k=1}^{N_{i}-1} w_{i k} X_{i k}\right]-\left[x_{E n g l i s h_{i}}^{\prime}+\sum_{k=1}^{N_{i}-1} w_{i k}^{\prime} X_{i k}^{\prime}\right]
\end{gathered}
$$

A problem with estimating equations 2-4 is that for those who are observed to choose integrated VET courses, we do not observe the counterfactual outcomes (second term in equations (3) and (4)), the classic evaluation problem. We use PSM to get around this problem by generating counterfactual outcomes that are weighted (matched) outcomes from $j$ students who did not take a VET course. Consistent with the underlying assumption of the matching (discussed above), we assume that the counterfactuals for the terms $w_{i A} x_{i A}, w_{i k}^{\prime} x_{i k}^{\prime}$ are mean weighted academic course scores from the control group $-\overline{w x_{j}} \cdot 12$

Assuming that the PSM function weights counterfactual outcomes by $g_{i j}$, a propensity score function, and substituting $\overline{w x_{j}}$ into equations (2)-(4), then the estimated total, direct and indirect effects for individual $i$ can be written as:

$$
\begin{gathered}
s_{i}-s_{i}^{\prime}=\left[x_{i E n g l i s h}+\sum_{k=1}^{N_{i}-1} w_{i k} x_{i k}+w_{i V E T} x_{i V E T}\right]-g_{i j}\left[x_{j E n g l i s h}+\overline{w X_{j}} \cdot N_{i}\right] \\
D E_{i}=\left[w_{i V E T} x_{i V E T}\right]-g_{i j}\left[\overline{w X_{j}}\right] \\
I E_{i}=\left[x_{i E n g l i s h}+\sum_{k=1}^{N_{i}} w_{i k} x_{i k}\right]-g_{i j}\left[x_{j E n g l i s h}+\overline{w X_{j}} \cdot N_{i}\right]
\end{gathered}
$$

\subsection{Specification of the propensity score function}

As mentioned above, for PSM to deal with self-selection bias, the CIA must hold, that is we must control for differences in all factors that affect both choice of integrated VET and outcomes of interest. Given the richness of our data, we are able to control for key individual differences including past academic performance and post-school study aspirations and school-level factors such as differences in peers and school type.

As shown in Table 2, one of the main differences between those who do and do not take integrated VET courses is differences in past academic performance, measured by performance in national standardised test scores (NAPLAN) in Year 9. Controlling for past

\footnotetext{
12 The mean weighted academic course score is calculated as: $\overline{w x_{j}}=\sum_{k=1}^{N_{j}} w_{j k} x_{j k} / N_{j}$
} 
academic achievement makes the interpretation of our results similar to that of a value-added model, which is assumed to largely account for differences in academic ability and the effects of historical investments in education (Hanushek 1979; Todd \& Wolpin 2003).

Another important student control is differences in post-school study aspirations between the two groups. It is possible that students who do and do not choose an integrated VET course may aspire to different university courses, so that there are also differences in academic courses taken between the two groups that may affect outcomes. We control for differences in field of education by including dummy variables for 25 fields of university study (2-digit ASCED) in the standard propensity score matching. In the standard estimation, we do not control explicitly for the level of aspiration, measured by the minimum university entry score of the first preference from the previous year, because this contains large numbers of missing observations that may affect the analysis. ${ }^{13}$ Results with this control are presented as part of the sensitivity analysis (section 5.3).

There is a body of literature that shows parents' education and occupational preferences are important in influencing student academic performance and occupational preferences (see for example Polidano et al. 2013). To control for this source of self-selection, we include information on the highest education level (Australian Standard Classification of Education (ASCED) 1-digit) and occupation skill level (Australian Standard Classification of Occupations (ASCO) 1-digit) of either parent into the selection equation.

Other individual-level information used in the matching is gender, age, indigenous status, whether the individual is from a non-English speaking background, remoteness of region, number of courses taken in Year 12 and a measure of regional disadvantage. We control for differences in local economic opportunities by using information on local (Statistical Local Area) unemployment rates from the Australian Bureau of Statistics. ${ }^{14}$

We use a range of controls for school-level differences between those who do and do not take an integrated VET course, which may also be related to differences in Year 12 scores. These include school type (public or private) Year 9 school-cohort mean estimates of numeracy and literacy (NAPLAN) scores, ${ }^{15}$ school size (proxied by the number of students in Year 12), and proportion of students in Year 12 who participate in at least one integrated VET course, a

\footnotetext{
${ }^{13}$ There are large numbers of missing observations because many first preferences are for courses that do not based admission exclusively on university entry scores.

${ }^{14}$ These were found to explain more of the variation in selection into integrated VET courses than indices of socio-economic disadvantage.

${ }^{15}$ For each student the school-cohort means are calculated leaving out score of the student.
} 
possible proxy for the quality and range of VET options in Year 12. We test the robustness of our results to omitted school-level factors in the sensitivity analysis presented in section 5.3.

We conduct post-match balancing tests to check for differences in the variable means of the treatment and matched control groups as proposed by Rosenbaum and Rubin (1985). Significant differences suggest that the CIA is violated. In the final specification of the probit selection model, there were no significant differences in mean characteristics of those who took an integrated VET course and the matched control group (balancing test results are presented in Figures A1, A2 and A3 in Appendix A). ${ }^{16}$

\section{Results}

The estimated Kernel results are presented in the tables below and represent the average treatment effects on the treated (ATET).

\subsection{Impacts on university entry scores}

Results presented in Table 3 suggest that controlling for non-random selection into integrated VET courses is important. Before the matching, there is a 17 point gap out of a possible 205 in the average university entry scores between those who take an integrated VET course and those who do not. After matching, the gap shrinks to around 5.47 points. This suggests that most of the unmatched gap (11 point gap) is due to non-random selection into integrated VET. The remaining 5.5 point, or $5 \%$, gap after matching can be interpreted as the reduction in the average university entry score associated with taking an integrated VET course.

Decomposition results presented in Table 3 suggest that most of the gap in matched entry scores (around 70\%) is related to a negative direct effect. More specifically, 3.97 points out of the 5.47 point gap in university entry scores can be explained by lower achievement in integrated VET courses, relative to what we estimate could have been achieved if an academic course had been chosen instead. ${ }^{17}$ The remainder of the gap, 1.51 points out of the 5.47 pointgap represents a negative spill-over effect that taking an integrated VET course has on academic achievement in other courses.

\footnotetext{
${ }^{16}$ Results from the balancing test are available upon request from the corresponding author.

${ }^{17}$ It is important to note that differences in achievement in this context are differences in the average contributions to the university entry score and not in the average scores. In this way we take into account the different weighting given to courses in making-up individual entry scores.
} 
Table 3: Estimated impacts from taking an integrated VET course on university entry scores (out of a maximum of 205) among those who apply to university, Kernel

\begin{tabular}{|c|c|c|c|c|c|c|c|}
\hline & \multicolumn{2}{|c|}{$\begin{array}{l}\text { Enrolled in an } \\
\text { integrated VET } \\
\text { course }\end{array}$} & \multicolumn{2}{|c|}{$\begin{array}{l}\text { Did not enrol in an } \\
\text { integrated VET } \\
\text { course }\end{array}$} & \multicolumn{2}{|l|}{$\begin{array}{l}\text { Difference } \\
\text { (ATET) }\end{array}$} & \multirow[t]{2}{*}{$\begin{array}{l}\text { Number } \\
\text { of obs. }\end{array}$} \\
\hline Overall & Avg. & s.e. & Avg. & s.e. & Avg. & s.e. & \\
\hline $\begin{array}{l}\text { Unmatched entry score } \\
\text { (out of 205) }\end{array}$ & 111.32 & 23.19 & 128.58 & 27.12 & $-17.26^{* * *}$ & 0.71 & 27,437 \\
\hline $\begin{array}{l}\text { Matched entry score } \\
\text { (out of 205) }\end{array}$ & 111.32 & 23.19 & 116.79 & 4.34 & $-5.47 * * *$ & 0.78 & 27,437 \\
\hline Decomposition results & & & & & & & \\
\hline Direct effect (out of 50) & 19.30 & 13.49 & 23.27 & 0.87 & $-3.97 * * *$ & 0.37 & 27,437 \\
\hline Indirect effect (out of 155) & 92.02 & 23.73 & 93.52 & 3.48 & $-1.51 * *$ & 0.71 & 27,437 \\
\hline $\begin{array}{l}\text { Results by prior academic perforn } \\
\text { Top } 25 \%\end{array}$ & ance (Yec & 9 nume & and literc & & & & \\
\hline $\begin{array}{l}\text { Unmatched entry score } \\
\text { (out of 205) }\end{array}$ & 144.31 & 17.21 & 159.36 & 21.18 & $-15.05^{* * *}$ & 2.75 & 3,041 \\
\hline $\begin{array}{l}\text { Matched entry score } \\
\text { (out of 205) }\end{array}$ & 144.97 & 16.78 & 143.72 & 10.72 & 1.25 & 5.84 & 3,032 \\
\hline Top 50-25\% & & & & & & & \\
\hline $\begin{array}{l}\text { Unmatched entry score } \\
\text { (out of 205) }\end{array}$ & 112.43 & 16.72 & 121.77 & 19.81 & $-9.34 * * *$ & 1.72 & 2,174 \\
\hline Matched entry score (out of 205) & 112.63 & 16.89 & 117.96 & 9.44 & $-5.32 * *$ & 2.72 & 2,170 \\
\hline
\end{tabular}

*Significant at $10 \%, * *$ significant at $5 \%, * * *$ significant at $1 \%$. Standard errors are calculated with bootstrap method with 1,000 replications.

${ }^{\mathbf{a}}$ The sample size for this sub-sample is disproportionately small because to be included, students must perform in this range in both numeracy and literacy.

The last row of Table 3 shows that the negative effect is concentrated among university aspirants who rank in the second top quartile in national tests in both literacy and numeracy (NAPLAN) in Year 9. These are students who may be considered on the margin of gaining university entry. ${ }^{18} \mathrm{~A}$ possible explanation for this finding is that university aspirants on the margin are not well suited and/or highly motivated to do well in VET courses. Figure 1 presents the distributions of VET and non-VET course score for these students. The figure shows that except for a small proportion of this group who perform extremely well in VET, students who apply for university courses achieve higher study scores in academic courses than in integrated VET courses. The opposite is true for students who do not apply for

\footnotetext{
${ }^{18}$ We choose performing in the second highest quartile (top 50-25\%) as being on the margin for university entry because academic performance is highly correlated with university entry and data from the Longitudinal Survey of Australian Youth (2003 cohort) suggests that around $40 \%$ of all Year 12 students are admitted to university.
} 
Figure 1: Distribution of Year 12 course scores for students who take integrated VET courses and are in the second top quartile (top 50-25\%) in national test scores in Year 9

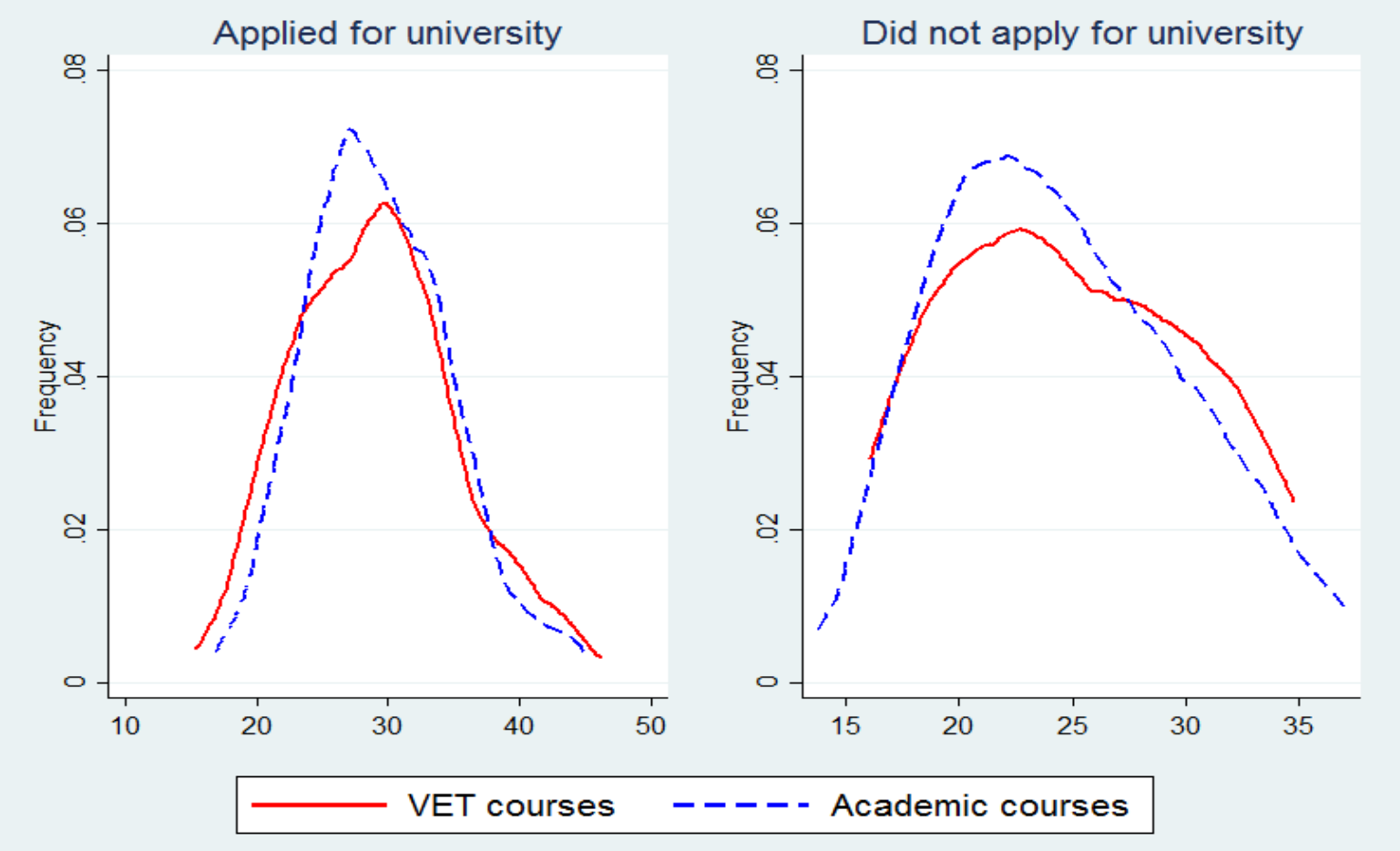

university and who perform similarly in national test scores in Year 9. ${ }^{19}$

The motivation of university aspirants on the margin may be relatively weak in these courses if they enrol in them only to establish possible fall-back options in the event they do not attain university access. In contrast, students who do not apply for university may be highly motivated to perform well in integrated VET courses because it prepares them for employment in their chosen career while still at school, either through the accumulation of credits towards a national qualification, or by preparing them for higher-level post-secondary VET qualifications. Unlike university aspirants, these students do not need to maximise their university entry score and can afford to specialise their efforts in VET. While most of these students still attain a university entry score, it is of no consequence for entry to employment or post-secondary VET study.

The negative indirect effect, albeit smaller than the direct effect, suggests a lack of complementarity between achievement in VET and in other academic courses. One explanation is that the 'hands-on' workplace context of VET is too far removed from the

\footnotetext{
${ }^{19}$ Results from the Kolmogorov-Smirnov one-sided tests are highly significant (p-values are less than 0.01).
} 
learning context in academic courses. Therefore the spill-over in achievement in other courses is lower than if another academic course is chosen instead. An additional or alternative explanation is that the training requirements may disrupt student performance in other courses. The high materials, equipment and staffing costs needed to run VET courses mean that, to offer a breadth of VET courses, many schools offer VET courses through partnering with local post-secondary VET providers or with other schools. As a result, students often have to take classes off the school campus, which may impact on the time spent in other classes.

\subsection{Impacts on university access}

Table 4: Estimated impacts from taking an integrated VET course on the chances of attaining entry to a university course, Kernel

\begin{tabular}{|c|c|c|c|c|c|c|c|}
\hline & \multicolumn{2}{|c|}{$\begin{array}{l}\text { Enrolled in an } \\
\text { integrated VET } \\
\text { course }\end{array}$} & \multicolumn{2}{|c|}{$\begin{array}{l}\text { Did not enrol in an } \\
\text { integrated VET course }\end{array}$} & \multicolumn{2}{|c|}{ Difference (ATET) } & \multirow[t]{2}{*}{$\begin{array}{l}\text { Number } \\
\text { of obs. }\end{array}$} \\
\hline & Avg. & s.e. & Avg. & s.e. & Avg. & s.e. & \\
\hline \multicolumn{8}{|c|}{ Imputed receipt of any offer (\%) } \\
\hline Unmatched & 0.559 & 0.497 & 0.755 & 0.430 & $-0.196 * * *$ & 0.011 & 29,600 \\
\hline Matched & 0.559 & 0.497 & 0.638 & 0.076 & $-0.080 * * *$ & 0.018 & 29,600 \\
\hline \multicolumn{8}{|c|}{ Imputed receipt of an offer for admission to a course that is at least the sixth most preferred (out of 12) } \\
\hline Unmatched & 0.509 & 0.500 & 0.686 & 0.464 & $-0.176^{* * *}$ & 0.012 & 29,266 \\
\hline Matched & 0.509 & 0.500 & 0.580 & 0.074 & $-0.070 * * *$ & 0.018 & 29,266 \\
\hline \multicolumn{8}{|c|}{ Imputed receipt of an offer for admission to a course that is at least the third most preferred (out of 12) } \\
\hline Unmatched & 0.404 & 0.491 & 0.543 & 0.498 & $-0.139 * * *$ & 0.013 & 28,271 \\
\hline Matched & 0.404 & 0.491 & 0.464 & 0.077 & $-0.060 * * *$ & 0.018 & 28,271 \\
\hline \multicolumn{8}{|c|}{ Self-reported receipt of an offer ${ }^{a}$} \\
\hline Unmatched & 0.675 & 0.469 & 0.864 & 0.342 & $-0.189 * * *$ & 0.012 & 16,923 \\
\hline Matched & 0.675 & 0.469 & 0.765 & 0.087 & $-0.090 * * *$ & 0.022 & 16,923 \\
\hline \multicolumn{8}{|c|}{$\begin{array}{l}\text { *Significant at } 10 \%, * * \text { significant at } 5 \%, * * * \text { significant at } 1 \% \text {. Standard errors are calculated with bootstrap method with } 1,000 \\
\text { replications. } \\
\text { a The number of observations for being offered a university place is less than in Table } 6 \text { because the sample is based on On Track data, which } \\
\text { is a sample of the population of school completers. The number of observations for attaining the preferred university preference and for } \\
\text { attaining one of the first three and first six preferences is higher than in table } 6 \text { because of the higher number of non-missing observations in } \\
\text { the outcome variable. }\end{array}$} \\
\hline
\end{tabular}

A key question is to what extent a 5.47 point lower score affects university access and the attainment of a preferred university offer. To answer this question we replicate our PSM 
procedure using as outcome our imputed binary measure of the receipt of any offer. We find that taking an integrated VET course is associated with an 8 percentage point lower chance of receiving a university offer (Table 4). This estimate is robust to the use of self-reported receipt of an offer, which also takes into account offers from courses that do not exclusively base admission on university entry scores. Taking an integrated VET course is also associated with a reduced chance of receiving a preferred offer, measured as admission to a top 6 or top 3 ranked course out of a possible 12 (Table 4).

Table 5: Estimated impacts from taking an integrated VET course on the chances of attaining entry to a university course by past academic performance, Kernel

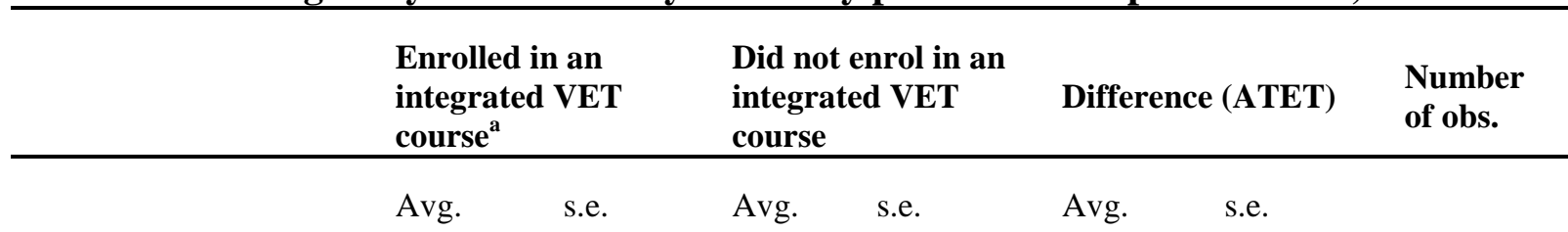

Top 25\% in Year 9 numeracy and literacy

Imputed receipt of any offer (out of a possible 12)

$\begin{array}{llllllll}\text { Unmatched } & 0.937 & 0.244 & 0.966 & 0.182 & -0.028 & 0.023 & 3,735 \\ \text { Matched } & 0.929 & 0.260 & 0.943 & 0.080 & -0.014 & 0.065 & 3,727\end{array}$

Self-reported receipt of an offer

$\begin{array}{llllllll}\text { Unmatched } & 0.913 & 0.285 & 0.979 & 0.142 & -0.066^{* * *} & 0.012 & 1,996 \\ \text { Matched } & 0.912 & 0.288 & 0.882 & 0.199 & 0.029 & 0.129 & 1,984\end{array}$

Top 50-25\% in Year 9 numeracy and literacy

Imputed receipt of any offer (out of a possible 12)

$\begin{array}{llllllll}\text { Unmatched } & 0.796 & 0.405 & 0.865 & 0.342 & -0.069 * * & 0.036 & 2,427 \\ \text { Matched } & 0.782 & 0.414 & 0.849 & 0.192 & -0.067 & 0.064 & 2,421\end{array}$

Self-reported receipt of an offer ${ }^{\mathrm{a}}$

\begin{tabular}{llllllll} 
Unmatched & 0.797 & 0.406 & 0.908 & 0.289 & $-0.112^{* * *}$ & 0.039 & 1,369 \\
Matched & 0.765 & 0.428 & 0.828 & 0.281 & -0.064 & 0.107 & 1,361 \\
\hline
\end{tabular}

*Significant at $10 \%, * *$ significant at $5 \%, * * *$ significant at $1 \%$. Standard errors are calculated with bootstrap method with 1,000 replications.

${ }^{\text {a }}$ The number of observations for being offered a university place is less than in Table 6 because the sample is based on On Track data, which is a sample of the population of school completers. The number of observations for attaining the preferred university preference and for attaining one of the first three and first six preferences is higher than in table 6 because of the higher number of non-missing observations in the outcome variable.

On face value, given that those who take an integrated VET course generally apply to courses with lower minimum entry scores than those who do not (Table 2), this large effect appears to be somewhat of a surprise. The key to understanding the relatively large effect on the chances 
of receiving an offer is the concentration of negative effects among those on the margin of attaining access to university. Compared to high performing students, a relatively small negative impact on university entry scores has a large impact on the chances of students on the margin receiving a university offer. This is demonstrated by the larger negative impacts estimated for those performing in the top and second top quartile in national test scores (Table 5), although the estimated impacts are not statistically significant due to the small sample sizes.

\subsection{Sensitivity analysis}

We test the robustness of our standard model results in Table 3 to the use of alternative matching methods and to the presence of selection bias that would occur if the CIA assumption is breached (Table 6). Overall, our results appear to be highly robust. We discuss each of the alternative scenarios and their results in turn below.

Table 6: Estimated impacts from taking an integrated VET course on university entry scores (out of a maximum of 205) under various assumptions

\begin{tabular}{|c|c|c|c|c|c|c|c|}
\hline & \multicolumn{2}{|c|}{$\begin{array}{l}\text { Enrolled in an } \\
\text { integrated VET } \\
\text { course }\end{array}$} & \multicolumn{2}{|c|}{$\begin{array}{l}\text { Did not enrol in an } \\
\text { integrated VET } \\
\text { course }\end{array}$} & \multicolumn{2}{|l|}{$\begin{array}{l}\text { Difference } \\
\text { (ATET) }\end{array}$} & \multirow[t]{2}{*}{$\begin{array}{l}\text { Number } \\
\text { of obs. }\end{array}$} \\
\hline & Avg. & s.e. & Avg. & s.e. & Avg. & s.e. & \\
\hline \multicolumn{8}{|l|}{ Standard results (from Table 3) } \\
\hline Unmatched & 111.32 & 23.19 & 128.58 & 27.12 & $-17.26^{* * *}$ & 0.71 & 27,437 \\
\hline Kernel matching (out of 205) & 111.32 & 23.19 & 116.79 & 4.34 & $-5.47 * * *$ & 0.78 & 27,437 \\
\hline \multicolumn{8}{|l|}{ Alternative matching methods } \\
\hline Nearest Neighbour, one-to-one & 111.32 & 23.19 & 117.06 & 24.30 & $-5.74 * * *$ & 1.25 & 27,437 \\
\hline Nearest Neighbour, closest five & 111.32 & 23.19 & 116.64 & 10.81 & $-5.32 * * *$ & 0.91 & 27,437 \\
\hline \multicolumn{8}{|l|}{$\begin{array}{l}\text { Kernel matching with additional } \\
\text { controls }\end{array}$} \\
\hline $\begin{array}{l}\text { With controls for entry score of } \\
\text { first preference }{ }^{\mathrm{a}}\end{array}$ & 111.72 & 22.80 & 116.50 & 23.22 & $-4.79 * * *$ & 0.63 & 21,603 \\
\hline $\begin{array}{l}\text { Exclude schools that don't offer } \\
\text { integrated VET courses }\end{array}$ & 111.32 & 23.19 & 116.50 & 3.88 & $-5.19 * * *$ & 0.77 & 22,146 \\
\hline
\end{tabular}


As discussed above, a down-side of using a Kernel estimator instead of Nearest Neighbour is that there is a greater risk of bias in small samples (Smith \& Todd 2005). To gauge the extent of any bias in this setting, we estimate results for one-to-one and closest-five Nearest Neighbour. The results are presented in Table 6 and are very close to the standard Kernel result, which suggests that our standard results are robust to the choice of matching method.

A key assumption in our analysis is the CIA. One reason it may be violated is if those students who take integrated VET courses have quite different post-school career aspirations from those who do not take VET courses. In particular, despite applying for university, those who choose VET courses may be more willing to follow career paths that do not involve university study, so that they are less highly motivated to achieve high grades. This may not be completely captured in the matching by including field of study dummies for students' first preferences. To test this, we re-estimate the standard model with the minimum entry score required for admission in 2010 of each student's preferred course included. Minimum entry scores from the previous year are a good indication of the academic requirements for entry in the existing year and entry scores for the preferred course should capture differences in academic ambition. Results with this variable included in the matching remain negative and significant, although the magnitude of the effect is slightly lower. It should be kept in mind that there is a considerable amount of missing observations under this scenario because some courses do not use entry scores for admission.

Another possible reason for a violation of the CIA would be the existence of unobserved differences in the schools attended by students who do and do not choose integrated VET courses. This may be particularly true between schools that do and do not offer integrated VET courses. To reduce this risk, we exclude around 6,000 control group members who attend schools that had no enrolments in any integrated VET course in 2011. Given that there may be potentially large differences in the nature of the schools that do and do not offer integrated VET courses, the robustness of our results under this scenario suggests any differences in schools not captured by the matching may be inconsequential for student outcomes.

While these results provide some confidence that any bias may not be large, we cannot rule it out. That said, the dominance of the direct effect from the decomposition analysis suggests that this is unlikely. In particular, the relatively low performance in integrated VET (that underpins the direct effect) means that if there are uncontrolled factors that lead to lower entry 
scores for VET students, then these factors must impact more on performance in integrated VET courses (direct effect) than performance in other courses (indirect effect). If any bias due to unobservable factors had the same effect on performance in all courses, then at the most, the bias would only account for around a third of the estimated gap in the matched university entry scores. $^{20}$

\section{Conclusions}

The tracking of students in upper-secondary school is often criticised for denying opportunities for VET students on the margin to enter university, which in some countries, causes upper-secondary VET courses to be stigmatised. To deal with this problem, countries have tended to either introduce technical colleges that provide a university equivalent qualification for students in the VET pathway or introduce integrated VET courses, which by combining aspects of academic and vocational courses, provide students with the flexibility to enter university, prepare for employment or pursue vocational post-secondary pathways. A challenge for these types of courses is catering for the large range of, potentially conflicting, student abilities and objectives.

In this paper, we provide the first evidence that the varied motivations and/or abilities of students within these courses are difficult to cater for, and that they may be, at least partly, responsible for lower academic achievement and university entry among university aspirants who take these courses. Using a decomposition approach developed for this study, we show that the bulk of the lower performance is due to relatively weak scores in integrated VET courses for those on the margin of attaining entry. These students may not be well suited to and/or highly motivated in these courses if they take them purely to increases their employability in the event they miss-out on a university place. This contrasts with the performance of students who did not apply for university, who perform relatively better in these courses than in academic courses, possibly because these courses are directly relevant to their desired career path.

Although a lack of data means that we are unable to conduct a full evaluation, our findings suggest that these courses are not meeting their primary objective, which is to improve the

\footnotetext{
${ }^{20}$ This is based on the assumption that the entire indirect effect is due to bias related to unobserved factors, which over the 4 courses that make up the indirect effect, gives a bias 0.38 points $(1.51 / 4)$ per course. If bias for performance in integrated VET is also 0.38 points, this would give a total bias of 1.9 points $(1.51+0.38)$ out of a total gap of 5.47 points, or a third of the gap.
} 
status of VET by opening-up pathways from upper-secondary VET to university study. ${ }^{21}$ Alternative models that allow flexible entry to bachelor courses from either upper-secondary path may be more effective in opening-up pathways to university than models that blend the upper-secondary curriculum in an attempt to meet academic-focussed university entry requirements. An example of an alternative model is the establishment of bachelor-degreeawarding technical colleges alongside established universities, which allow students to continue their vocational studies to a university level. In Finland at least, such reforms have improved the status of VET (Stenström and Virolainen, 2014), although the labour market outcomes have proven to be limited (Böckerman et al. 2009). Another approach is to encourage universities to adopt more flexible admission procedures. This may be especially the case when considering admission to courses for which there are closely related uppersecondary VET courses, such as business, information technology and engineering courses. The development of more dual-sector universities may be one way to encourage greater recognition of upper-secondary VET study by universities.

A second main contribution of our paper is in the development of a decomposition framework that can be used to separate any effects from course choice according to direct and spill-over effects. We find evidence of a small, but significantly negative spill-over effect from VET study, which suggests that taking these is detrimental to performance in other courses. This contradicts the theory of experiential learning that proposes the need for applied settings to help motivate engagement in study (Kolb 1984). In future studies, this framework may be used to examine spill-overs for other courses, especially for enabling courses, such as information technology and research methods.

\footnotetext{
${ }^{21}$ To conduct a full evaluation, more data is needed on the outcomes from study, including qualification attainment and employment outcomes.
} 


\section{References}

Australian Bureau of Statistics (ABS) 2006, Census of Population and Housing: Socio-economic Indexes for Areas (SEIFA), cat. no. 2033.0.55.001, ABS, Canberra.

Australian Curriculum, Assessment and Certificate Authorities (ACACA) 2012, VET in Senior Secondary, Certificates of Education 2012, Board of Studies NSW, Sydney.

Bishop, JH and Mane, F 2004 'The impacts of career-technical education on high school labor market success', Economics of Education Review, vol. 23(4), 381-402.

Böckerman, P, Hämäläinen, U, \& Uusitalo, R 2009, 'Labour market effects of the polytechnic education reform: The Finnish experience', Economics of Education Review, vol. 28(6), pp. 672-681.

Ding, W, \& Lehrer, SF 2007. 'Do peers affect student achievement in China's secondary schools? ', The Review of Economics and Statistics, vol. 89(2), 300-312.

Eichhorst, W, Rodriquez-Planas, N, Schmidl, R, Zimmermann, K 2015. 'A roadmap to vocational education and training systems around the world', Industrial and Labor Relations Review, vol. 68(2), pp.314-337.

Fazekas, M and Field, S 2013. 'A Skills beyond School Review of Switzerland', OECD, Paris.

Hanushek, E 1979, 'Conceptual and empirical issues in the estimation of educational production functions', The Journal of Human Resources, vol. 14(3), pp. 351-88.

Kang, S \& Bishop, J 1989, 'Vocational and academic education in high school: Complements or substitutes?', Economics of Education Review, vol. 8(2), pp. 133-148.

Kogan, I 2008, Education systems of Central and Eastern European countries. In Irena Kogan, Michael Gebel and Clemens Noelke (Eds.), Europe Enlarged: A Handbook of Education, Labour and Welfare Regimes in Central and Eastern Europe, pp. 7-34. Bristol: Policy Press.

Kolb, D 1984, Experiential learning: experience as a source of learning and development, Prentice Hall, New York.

Kuczera, M \& Field, S 2013, 'A Skills beyond School Review of the United States', OECD Reviews of Vocational Education and Training, OECD, Paris.

Lamb, S \& Vickers, M 2006, Variations in VET provision across Australian schools and their effects on student outcomes, LSAY Research Report no. 48, Australian Centre for Education Research, Melbourne.

Meer, J 2007, 'Evidence on the returns to secondary vocational education', Economics of Education Review, vol. 26, pp. 559-573.

Ministerial Council on Employment Education and Training and Youth Affairs (MCEETYA) 1999, The Adelaide declaration on national goals for schooling in the twenty-first century, MCEETYA, Canberra.

MCEETYA 2001, New framework for vocational education in schools: a comprehensive guide about pathways for young Australians in transition, MCEETYA, Canberra.

Organisation for Economic Co-operation and Development (OECD) 2000, From initial education to working life, making transitions work. OECD, Paris.

OECD 2013, Education at a glance, OECD, Paris.

OECD 2014, 'Skills Beyond Schools: Synthesis Report', OECD Reviews of Vocational Education and Training, OECD, Paris. 
Polidano, C, Hanel, B \& Buddelmeyer, H 2013, 'Explaining the SES gap in school completion', Education Economics, vol. 21(3), pp. 230-247.

Polidano, C \& Tabasso, D 2014, 'Making it real: the benefits of workplace learning in uppersecondary vocational education and training courses', Economics of Education Review, vol. 42, 120-136.

Smith, J 2002, 'Learning styles: fashion fad or lever for change? The application of learning style theory to inclusive curriculum delivery', Innovations in Education and Teaching International, vol. 39(1), pp. 63-70.

Stenström, M \& Virolainen, M 2014, 'The current state and challenges of vocational education and training in Finland', Finish Institute of Educational Research, University of Jyväskylä.

Todd, P \& Wolpin, K 2003, 'On the specification and estimation of the production function for cognitive achievement', The Economic Journal, vol. 113, pp. F3-F33.

Victorian Curriculum and Assessment Authority (VCAA) 2010, VCE VET Assessment Guide, VCAA, Melbourne.

VCAA 2011, 2011 Scaling Report, VCAA, Melbourne.

VCAA 2011, An overview of VET in the VCE and VCAL, VCAA, Melbourne.

Victorian Tertiary Admission Centre (VTAC) 2011, ABC of scaling, VTAC, Melbourne.

Woessmann, L 2008. 'Efficiency and equity of European education and training policies', International Tax and Public Finance, vol. 15(2), pp. 199-230. 


\section{Appendix A: Additional descriptive statistics and other results}

Table A1: Mean values of students' family and school characteristics

\begin{tabular}{|c|c|c|c|c|}
\hline & \multicolumn{2}{|c|}{$\begin{array}{c}\text { Applied for } \\
\text { university } \\
\text { (sample for analysis) }\end{array}$} & \multicolumn{2}{|c|}{$\begin{array}{l}\text { Did not do not apply } \\
\text { for university } \\
\text { (omitted from the }_{\text {sample) }}{ }^{\mathrm{a}}\end{array}$} \\
\hline & $\begin{array}{l}\text { Integrated } \\
\text { VET } \\
\text { students }\end{array}$ & $\begin{array}{l}\text { Other } \\
\text { students }\end{array}$ & $\begin{array}{l}\text { Integrated } \\
\text { VET } \\
\text { students }\end{array}$ & $\begin{array}{l}\text { Other } \\
\text { students }\end{array}$ \\
\hline \multicolumn{5}{|l|}{ Students' family characteristics } \\
\hline \multicolumn{5}{|l|}{ Highest ANZSCO occupation among parents } \\
\hline Not stated & 11.18 & 11.83 & 7.94 & 8.23 \\
\hline Not in paid work & 8.34 & 5.81 & 6.42 & 8.40 \\
\hline Labourer & 14.97 & 12.05 & 19.48 & 19.60 \\
\hline Tradesman/clerk & 20.66 & 17.22 & 26.66 & 26.57 \\
\hline Other manager & 26.22 & 25.25 & 27.20 & 24.66 \\
\hline Senior managers, qualified professionals & 18.64 & 27.84 & 12.30 & 12.55 \\
\hline \multicolumn{5}{|l|}{ Highest ASCED education level among parents } \\
\hline Not stated & 13.01 & 12.42 & 9.47 & 9.96 \\
\hline Year 9 or below & 2.91 & 2.56 & 2.07 & 3.15 \\
\hline Year 10/11 & 10.23 & 7.38 & 17.52 & 16.47 \\
\hline Year 12 & 9.48 & 8.94 & 9.90 & 10.18 \\
\hline VET level ISCED 2-4 & 25.96 & 19.46 & 31.23 & 30.39 \\
\hline Diploma & 14.47 & 14.52 & 14.91 & 15.65 \\
\hline Bachelor degree or above & 23.94 & 34.71 & 14.91 & 14.20 \\
\hline \multicolumn{5}{|l|}{ School characteristics } \\
\hline Non-government school (\%) & 45.48 & 53.35 & 30.24 & 31.18 \\
\hline School average NAPLAN numeracy score (out of 692) & 599.05 & 613.07 & 592.87 & 595.09 \\
\hline School average NAPLAN reading score (out of 692) & 594.00 & 603.99 & 588.56 & 590.64 \\
\hline School average $\%$ of students taking integrated $\mathrm{VET}^{\mathrm{b}}$ & 6.78 & 3.85 & 6.95 & 4.84 \\
\hline Inner Regional Australia (\%) & 15.48 & 13.86 & 17.09 & 20.04 \\
\hline Major Cities of Australia (\%) & 65.19 & 68.02 & 59.26 & 54.69 \\
\hline Outer Regional Australia (\%) & 2.65 & 2.47 & 3.48 & 4.14 \\
\hline Mixed location (\%) & 16.68 & 15.65 & 20.16 & 21.13 \\
\hline
\end{tabular}


Table A2: The ten most common academic courses taken by students who do and do not take a VCE course

\begin{tabular}{|c|c|c|c|c|c|}
\hline \multicolumn{2}{|c|}{$\begin{array}{l}\text { Students who take a VCE VET } \\
\text { course (treatment group) }\end{array}$} & \multicolumn{2}{|c|}{$\begin{array}{l}\text { Students who don't take a VCE } \\
\text { VET course (control group) }\end{array}$} & \multicolumn{2}{|l|}{ Matched control group } \\
\hline & $\%$ & & $\%$ & & $\%$ \\
\hline Further Mathematics & 19.81 & Further Mathematics & 14.32 & Further Mathematics & 16.19 \\
\hline $\begin{array}{l}\text { Health \& Human } \\
\text { Development }\end{array}$ & 7.66 & $\begin{array}{l}\text { Mathematical Methods } \\
\text { (CAS) }\end{array}$ & 8.86 & Business Management & 7.74 \\
\hline Business Management & 7.56 & Psychology & 7.09 & Psychology & 7.50 \\
\hline Psychology & 6.35 & Chemistry & 5.80 & $\begin{array}{l}\text { Health \& Human } \\
\text { Development }\end{array}$ & 6.43 \\
\hline Physical Education & 5.93 & $\begin{array}{l}\text { Health \& Human } \\
\text { Development }\end{array}$ & 5.37 & Physical Education & 5.83 \\
\hline Studio Arts & 4.17 & Biology & 5.33 & Biology & 5.24 \\
\hline $\begin{array}{l}\text { Visual Communication \& } \\
\text { Design }\end{array}$ & 4.08 & Business Management & 5.10 & $\begin{array}{l}\text { Mathematical Methods } \\
\text { (CAS) }\end{array}$ & 4.88 \\
\hline Media & 3.64 & Physical Education & 4.44 & Studio Arts & 4.76 \\
\hline $\begin{array}{l}\text { Mathematical Methods } \\
\text { (CAS) }\end{array}$ & 3.58 & Physics & 3.81 & $\begin{array}{l}\text { Visual Communication \& } \\
\text { Design }\end{array}$ & 4.52 \\
\hline Food \& Technology & 3.23 & Legal Studies & 3.76 & Legal Studies & 3.93 \\
\hline
\end{tabular}


Table A3: Results from the probit model of participation in a VCE VET course used in the propensity score matching

\begin{tabular}{|c|c|c|c|c|}
\hline & \multicolumn{2}{|l|}{ All students } & \multicolumn{2}{|c|}{$\begin{array}{l}\text { Students that intend to } \\
\text { start higher education }\end{array}$} \\
\hline & $\begin{array}{l}\text { Marginal } \\
\text { effect }\end{array}$ & t-stat & $\begin{array}{l}\text { Marginal } \\
\text { effect }\end{array}$ & t-stat \\
\hline \multicolumn{5}{|l|}{ Individual characteristics } \\
\hline Respondent is male & $0.00211^{* * *}$ & $(2.59)$ & $0.00116 *$ & $(1.87)$ \\
\hline Age of respondent (years) & -0.00107 & $(-1.42)$ & -0.000684 & $(-1.22)$ \\
\hline Indigenous status & -0.00461 & $(-1.33)$ & -0.00312 & $(-1.48)$ \\
\hline Non-English speaking background & 0.000547 & $(0.60)$ & -0.000264 & $(-0.41)$ \\
\hline Rural area & $-0.000922 * * *$ & $(-3.29)$ & $-0.000582 * * *$ & $(-2.69)$ \\
\hline Unemployment rate in SLA (\%) & -0.000173 & $(-1.12)$ & -0.00000621 & $(-0.05)$ \\
\hline NAPLAN numeracy score in Year 9 (out of 874) & $-0.00004^{* * *}$ & $(-4.60)$ & $-0.000024 * * *$ & $(-3.75)$ \\
\hline NAPLAN reading score in Year 9 (out of 874) & $-0.0000154^{*}$ & $(-1.92)$ & $-0.0000131 * *$ & $(-2.19)$ \\
\hline Number of courses taken in VCE & $0.0165^{* * *}$ & $(7.68)$ & $0.0104^{* * *}$ & $(6.45)$ \\
\hline Taken VET courses at unit 1 or 2 level & $0.00275^{* * *}$ & $(15.72)$ & $0.00174 * * *$ & $(11.36)$ \\
\hline \multicolumn{5}{|l|}{ School level factors } \\
\hline Non-government school & $0.00585^{* * *}$ & $(6.02)$ & $0.00352 * * *$ & $(4.97)$ \\
\hline $\begin{array}{l}\text { School average NAPLAN numeracy score (out of } \\
692)^{\mathrm{a}}\end{array}$ & -0.0000214 & $(-0.75)$ & -0.000009 & $(-0.48)$ \\
\hline School average NAPLAN reading score (out of 692) ${ }^{\mathrm{a}}$ & $-0.0000648 *$ & $(-1.80)$ & -0.0000265 & $(-1.00)$ \\
\hline School average \% of students taking integrated $\mathrm{VET}^{\mathrm{a}}$ & -0.0000009 & $(-0.01)$ & $0.000120 *$ & $(1.69)$ \\
\hline Number of Year 12 students in the school & $0.0000353 * * *$ & $(7.59)$ & $\begin{array}{l}0.0000217^{* *} \\
*\end{array}$ & $(6.06)$ \\
\hline
\end{tabular}

Highest ANZSCO occupation among parents (ref. case: senior managers, qualified professionals)

$\begin{array}{lllll}\text { Not stated } & 0.00357 & (1.42) & 0.00112 & (0.68) \\ \text { Not in paid work } & 0.00377 & (1.53) & 0.00405^{*} & (1.81) \\ \text { Labourer } & 0.00374^{*} & (1.95) & 0.00250^{*} & (1.66) \\ \text { Tradesman/clerk } & 0.00140 & (0.97) & 0.00157 & (1.36) \\ \text { Other manager } & 0.00308^{* *} & (2.22) & 0.00181^{*} & (1.81)\end{array}$

Highest ASCED education level among parents (ref. case: Bachelor degree or above)

$\begin{array}{lllll}\text { Not known } & 0.00122 & (0.63) & 0.00242 & (1.39) \\ \text { Year 9 or below } & -0.00256 & (-1.43) & -0.00163 & (-1.29) \\ \text { Year 10/11 } & -0.000156 & (-0.11) & -0.000468 & (-0.46) \\ \text { Year 12 } & -0.00104 & (-0.79) & -0.00132 & (-1.54) \\ \text { VET level ISCED 2-4 } & -0.000986 & (-0.89) & -0.000472 & (-0.58) \\ \text { Diploma } & -0.00165 & (-1.53) & -0.00102 & (-1.33)\end{array}$

Intended field of education at university (ASCED code for first preference (ref. case: Maths and Science) ${ }^{b}$

Other Natural and Physical Sciences

$\begin{array}{llll}-0.00636 * * * & (-6.18) & -0.00473 * * * & (-8.54) \\ -0.00599 * * * & (-6.16) & -0.00635 * * * & (-5.68)\end{array}$

Computer Science and IT Systems 


\begin{tabular}{|c|c|c|c|c|}
\hline Other IT & 0.000694 & $(0.24)$ & $-0.00438 * * *$ & $(-5.88)$ \\
\hline Engineering, Manufacturing \& Technology & $0.0194 * * *$ & $(3.05)$ & -0.00323 & $(-1.38)$ \\
\hline Maritime Engineering and Technology & -0.00298 & $(-1.51)$ & $-0.00466 * * *$ & $(-7.32)$ \\
\hline Other Engineering and Technology & $-0.00347^{* *}$ & $(-2.06)$ & $-0.00471 * * *$ & $(-8.42)$ \\
\hline Architecture and Building & $-0.00389 * *$ & $(-2.21)$ & $-0.00470 * * *$ & $(-8.09)$ \\
\hline Agriculture; Natural Resources \& Environment & $-0.00429 * * *$ & $(-3.66)$ & $-0.00491 * * *$ & $(-7.38)$ \\
\hline Other Agriculture and Related Studies & $-0.00462 * * *$ & $(-3.40)$ & $-0.00479 * * *$ & $(-8.19)$ \\
\hline Medical Studies; Pharmacy and Nursing & -0.00497 & $(-1.52)$ & $-0.00450 * * *$ & $(-8.69)$ \\
\hline Veterinary Studies, Public Health \& Related & $-0.00528 * * *$ & $(-5.70)$ & $-0.00645 * * *$ & $(-5.03)$ \\
\hline Other Health & $-0.00471^{* * *}$ & $(-4.21)$ & $-0.00541^{* * *}$ & $(-6.69)$ \\
\hline Teacher Education; Curriculum and Education Studies & $\mathrm{S}-0.00335^{* * *}$ & $(-2.58)$ & $-0.00511^{* * *}$ & $(-6.47)$ \\
\hline Other Education & -0.000384 & $(-0.25)$ & $-0.00515^{* * *}$ & $(-4.90)$ \\
\hline Accounting, Business, Marketing \& Related & 0.000788 & $(0.22)$ & $-0.00438 * * *$ & $(-6.57)$ \\
\hline Banking and Finance \& Related & -0.00139 & $(-1.16)$ & $-0.00604 * * *$ & $(-4.33)$ \\
\hline Other Management and Commerce & -0.00439 & $(-1.39)$ & $-0.00449 * * *$ & $(-8.64)$ \\
\hline Behavioural Science, Law \& Related & $-0.00662 * * *$ & $(-7.55)$ & $-0.00553 * * *$ & $(-7.33)$ \\
\hline $\begin{array}{l}\text { Language and Literature, Economics, Philosophy \& } \\
\text { Related }\end{array}$ & $-0.00314^{* * *}$ & $(-2.71)$ & $-0.00630 * * *$ & $(-4.61)$ \\
\hline Sport and Recreation & -0.00115 & $(-0.47)$ & $-0.00454^{* * *}$ & $(-7.72)$ \\
\hline Other Society and Culture & 0.00208 & $(0.76)$ & $-0.00439 * * *$ & $(-6.03)$ \\
\hline Arts, Design, Media Studies \& Related & $-0.00566^{* * *}$ & $(-6.23)$ & $-0.00614^{* * *}$ & $(-5.65)$ \\
\hline Other Creative Arts & 0.00256 & (1.58) & $-0.00534^{* * *}$ & $(-3.47)$ \\
\hline Personal Services & $0.0158 *$ & $(1.88)$ & $-0.00383 * * *$ & $(-2.79)$ \\
\hline Observations & 32562 & & 27437 & \\
\hline
\end{tabular}

***Significant at $1 \%$, ** significant at $5 \%,{ }^{*}$ significant at $10 \%$.

${ }^{a}$ Excluding student's own outcome.

${ }^{\mathrm{b}}$ These headings reflect the 2-digit ASCED fields of study based on the 4-digit headings that makeup the 2-digit categories. 
Figure A1: Reduction in bias among covariates for university entry scores

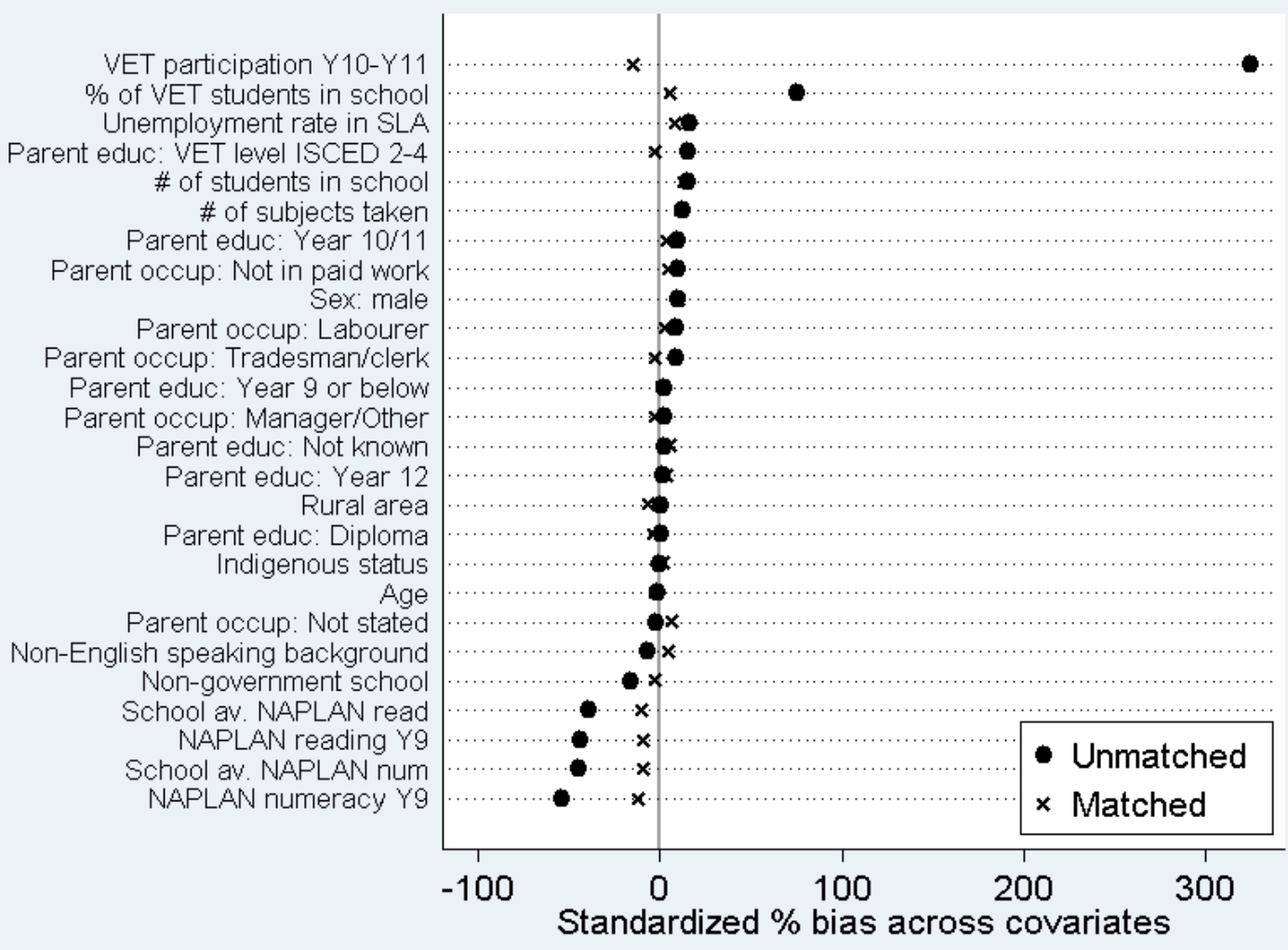


Figure A2: Reduction in bias among covariates, imputed receipt of any university offer

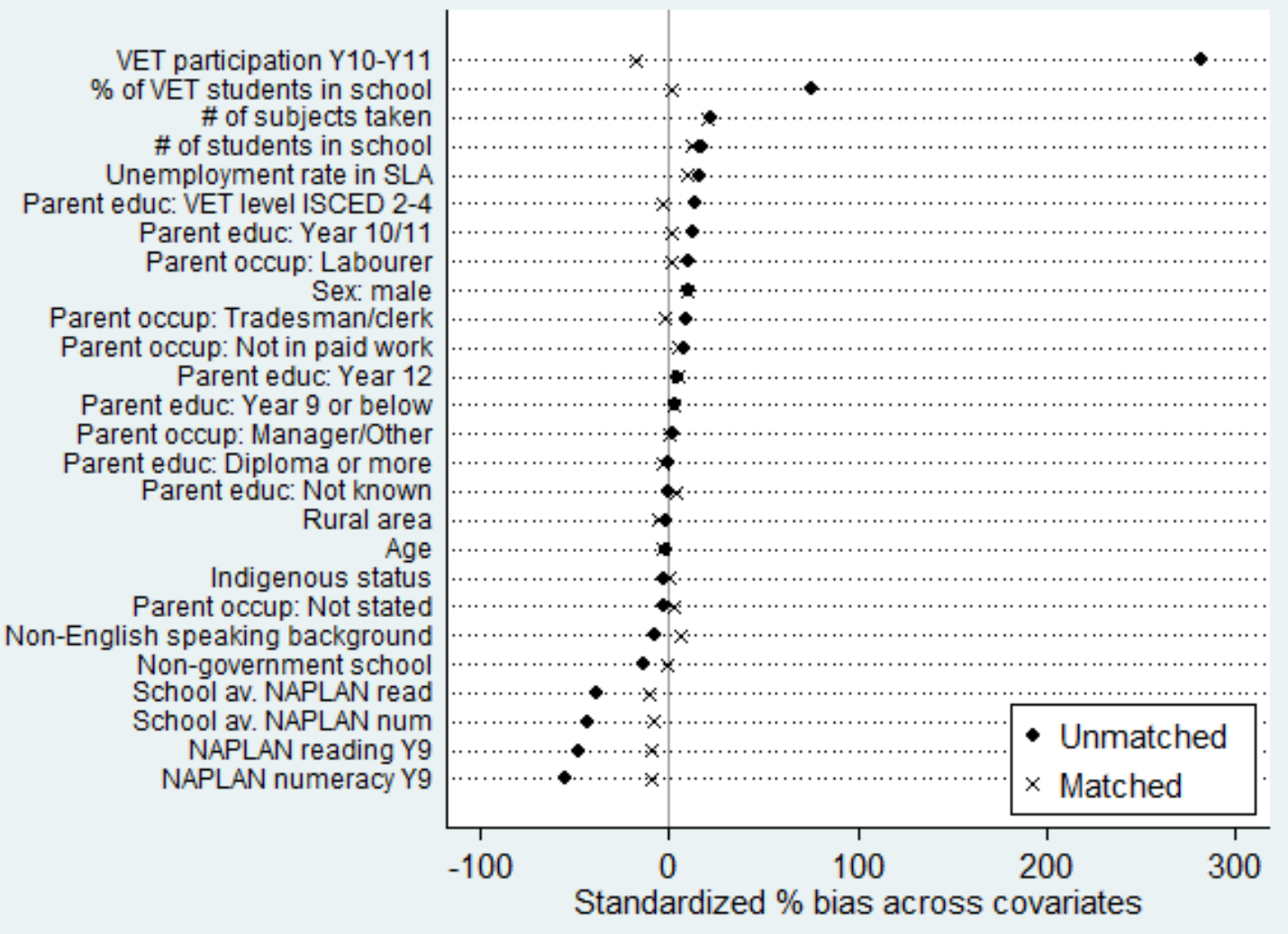


Figure A3: Reduction in bias among covariates, self-reported receipt of any university offer

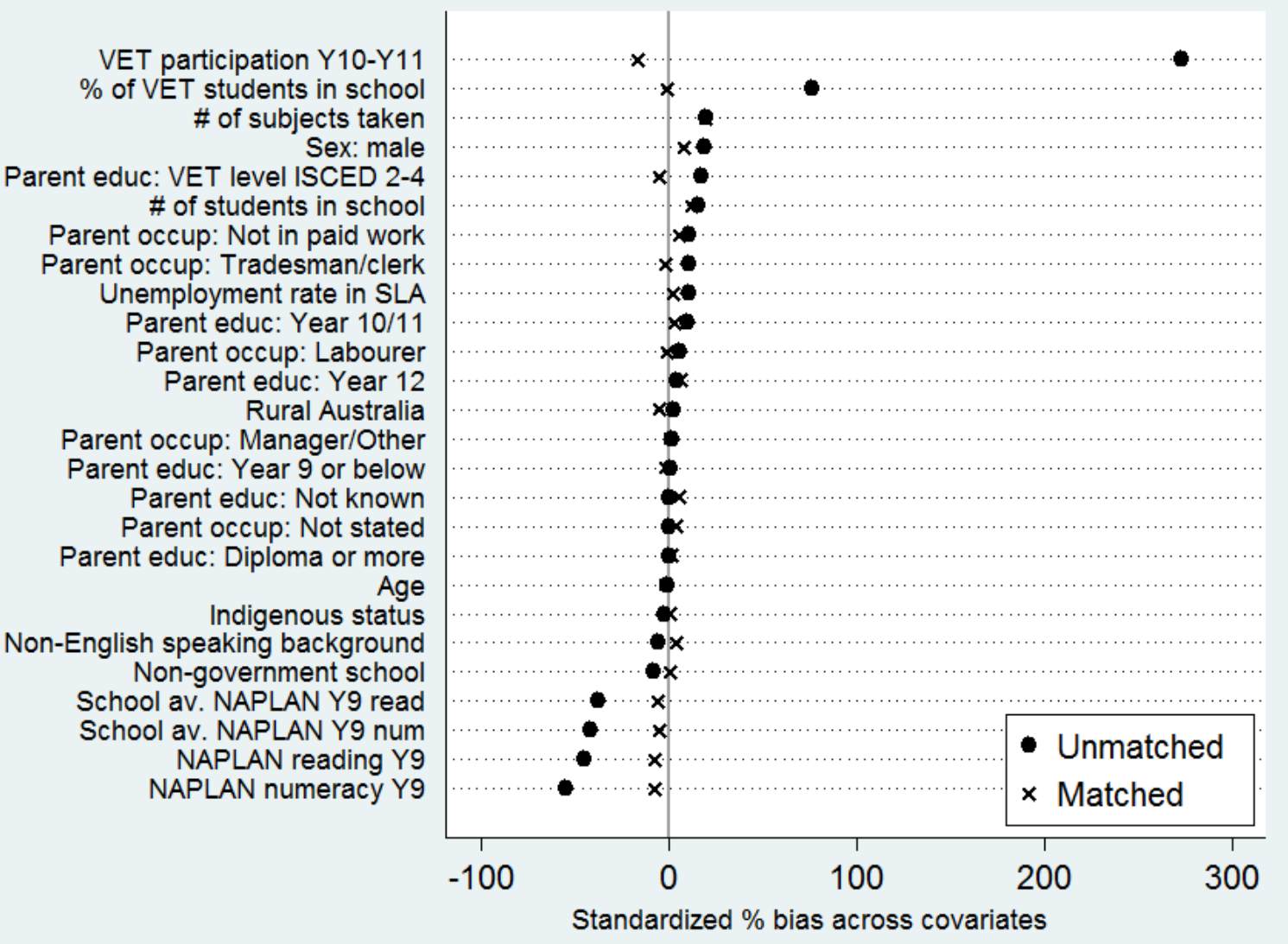




\section{University Library}

\section{- M M I N E R VA A gateway to Melbourne's research publications}

Minerva Access is the Institutional Repository of The University of Melbourne

Author/s:

Polidano, C;Tabasso, D

Title:

Fully integrating upper-secondary vocational and academic courses: A flexible new way?

\section{Date:}

2016-12-01

Citation:

Polidano, C. \& Tabasso, D. (2016). Fully integrating upper-secondary vocational and academic courses: A flexible new way?. Economics of Education Review, 55, pp.117-131. https://doi.org/10.1016/j.econedurev.2016.09.001.

Persistent Link:

http://hdl.handle.net/11343/123518 